\title{
Impact of educational program on knowledge, attitude and preventive behaviors related to HIV STIs in female sex workers in Shiraz south Iran
}

\author{
Mahmood Amini Lari, Minoo Ali pour Sakha, Farbod Ebadi Far Azra, Parvin Afsar Kazerooni, Mehrab Sayadi \\ From 17th International Symposium on HIV and Emerging Infectious Diseases (ISHEID) \\ Marseille, France. 23-25 May 2012
}

\section{Background}

Female sex workers (FSW) have been well identified as core groups that play an important role in the effluence of sexually transmitted diseases (STD) and HIV. The purpose of present study was to assess the impact of educational intervention on promoting STIs / HIV related knowledge, attitude and preventive behaviors among female sex workers In Shiraz Iran in 2009.

\section{Methods}

In this quasi-experimental study with a pre-test -post-test design which was conducted from February to July 2009, 80 female sex workers were selected from 5 Shiraz Drop in Centers using the classified random sampling technique. At the beginning FSWs' HIV/STI related information was assessed in a safe place by interview, using standard questioners as pre-test and then educational intervention program (lecture, face to face education, pamphlet, educational movie, role playing health educational competition) have performed. After 2 months post test was administered to evaluate the effect of interventional program.

\section{Results}

The average age of the participants was $32.62 \pm 9.11$ and the average number of participants' partners was 4 (range 1-15).After the educational intervention, there was a significant difference between the pre-test and post-test knowledge scores ,it means that the mean score of general knowledge related to HIV/STI increased from $13.7 \pm 0.95$ to $19.47 \pm 11.62(\mathrm{P}<0.01)$. Similarly, there was a significant improvement in the sex workers' attitude and their sexual

* Correspondence: maminil@yahoo.com

Shiraz HIV/AIDS Research Center, Shiraz, Israel preventive behaviors such as safe sex and condom use $(\mathrm{P}<0.01)$.

\section{Conclusion}

According to results of this study, the educational program was successful in increasing and promoting the HIV/AIDS-related knowledge and attitudes of the participants and enhancing their HIV sexual risk behaviors. More interventional studies should be developed for other high risk population.

Published: 25 May 2012

doi:10.1186/1742-4690-9-S1-P97

Cite this article as: Lari et al:: Impact of educational program on

knowledge, attitude and preventive behaviors related to HIV STIs in

female sex workers in Shiraz south Iran. Retrovirology 2012 9(Suppl 1):P97.
Submit your next manuscript to BioMed Central and take full advantage of:

- Convenient online submission

- Thorough peer review

- No space constraints or color figure charges

- Immediate publication on acceptance

- Inclusion in PubMed, CAS, Scopus and Google Scholar

- Research which is freely available for redistribution
C Biomed Central 